\title{
Imaginative Reality in Ed Bullins's Drama
}

Sanjay Kumar Mishra

https://doi.org/10.3126/litstud v29i01.39613

\section{Abstract}

Ed Bullins's drama makes relentless exploration of inner forces that help African-American people realize their freedom and potential. In directing his attention to this concern, Bullins assumes that America has formed and deformed aspects of the black experience and consciousness. The things that most interest Bullins reside within his characters and are of their own choosing; even his portrayal of interracial characters focuses on the behavior of the black characters. In his plays, a black stage reality and black audience are assumed. The matters he takes up often are intimate, sensitive, and particular to the black experience.

\section{Introduction}

Ed Bullins arrived in New York in 1967. Then he established his reputation quickly. He went there at the invitation of Robert Macbeth, the director of the New Lafayette Players, a company of black actors and actresses who had been working together for several years. Macbeth wanted Bullins to write for the company, which had just opened a theater in Harlem. In this ideal situation, Bullins's considerable talent flourished (Sanders 177). In this article, I shall try to explore how Bullins was influenced by Ameri Baraka (LeRoi Jones), but at the same time I shall also try to explore while Baraka chose the theater of symbol and allegory to show the beautiful themselves, Bullins chose what he termed a "theatre of reality." As he says, "any theatrical style or method can be used separately or in combination to reach the truth of the play ... dramatizing the journey of the character through his own psyche to reach his loss of innocence, self-awareness or illumination. To reach what individually is called reality. The method is not the goal in this theatre; the result must elicit the single response of "Yes!" ("Theatre" 65). The penetrating honesty characteristic of his work indicates his imaginative and literary assurance.

\section{Methods}

Bullins's dramatic focus has remained consistent throughout more than fifty plays. As this is an article of not more than twenty-five hundred words, all his plays are not possible to include here. To address the issue, I shall make critical examinations of some of his well-known plays by analyzing interviews, notes, and a few critics' commentaries.

\section{Discussion}

Bullins's plays express contemporary black theatre's new artistic freedom and maturity. The stage reality Bullins assumes, the themes he chooses, the characters and settings he creates, and the language he uses clearly build on the work of his predecessors. He pursues his central theme, the inner constraints hampering freedom, in his plays of the Black Revolutionary Theatre, which comment directly on political revolutionary concerns. In his plays on Race Relations, he examines the relation between white and black races from a social perspective. And in his Theatre of Black Experience plays, he depicts life of black communities in America. 
Bullins, in his attempt to establish a particular relationship with his audience, uses street language and builds up a sense of black world. His attitude toward his audience is, at least, in part influenced by Baraka. On his productions of In the Wine Time and We Righteous Bombers, Macbeth commented:

In the theatre we're finally going to reach the point where the communication between the people who perform the rituals and the people who sit through them-the communication will be much more direct; it will even be physical, the actors will touch the audience and the audience will then come with the actors into the play. (Interview with Marvin X, 21)

Audience participation in a Bullins play is sometimes literal, as in It Bees Dat Way. The audience is admitted into a room with only a streetlamp to suggest a Harlem street corner. The actors, portraying various street types, molest the white members of the audience at will, jostling them, soliciting the men, propositioning the women, and picking pockets. Finally, as the atmosphere becomes abrasive and violent, the whites are slowly dismissed from the room because as one character admonishes the others:

Des hare people ain't the ones to get ... they ain't got nothin' . . . just like you and me ... they just work for them that made dis mess. ... The ones to shoot is who what made this mess.

(It Bees, 15)

In this play, both Blacks and Whites are challenged to act and their responses reveal their basic racial and social attitudes. It pointedly actualizes the experience whites desired when they flocked to Baraka's plays to, as Mick Jagger says, "get their fair share of abuse" (qtd. in Sanders 181). However, ultimately the play addresses the members of its black audience, for they alone remain after the whites have been ushered out and the final comments are addressed to them.

In In the Wine Time, Bullins not only invites audience participation but challenges his audience to identify with and thus at least imaginatively join the activities on stage. In this play, two central characters, Cliff Dawson and his wife, Lou, are passing a summer evening lounging on their front stoop, drinking wine. Early in the play, they quarrel over their boisterousness, resented by their neighbors:

Cliff: (Raises his voice) Make up yo' mind, broad. Now what is it ... do we cuss and drink like sailors or cuss like sailors and drink like ... like... what?

Lou: Like niggers (At the last word lights go up on the other stoops, revealing the occupants looking at Cliff and Lou. (Wine 123)

Nigger in this context is a black word, the term of insult and endearment spoken by Blacks among themselves and thus a mark of the stage reality giving rise to Lou's utterance. Moreover, her comment is not simply an address to the audience but may be taken as "signifying" an invitation to respond. Bullins suggests that any audience of his play is in danger, particularly if it comes to understand what it witnesses.

Baraka's plays portray the stage takeover: in almost all his plays, the stage reality is either contested or transformed through exorcism. In a Bullins play, the process is complete, the play opens assuming the black stage reality, and proceeds with the kinds of explorations that such a reality is possible. Bullins establishes his dramatic world, in part, through language and music. As Lindsay Patterson observes, Bullins has a "wonderful ear for the language of the ghetto" 
(7). In The Toilet, Baraka similarly uses crude street language, but the effect is different; it is a challenge to his audience and a comment on the world depicted. Unlike Baraka, Bullins makes the speech lyrical. He delights in black street argot and reveals its lyricism while keeping its harshness intact. His plays disclose that ghetto speech ultimately reflects a brutality the speakers turn first on themselves, and that the speech is equally capable of eloquently expressing his characters' search for love, affection, faith, and security.

In Bullins's plays concerning social relationship between Blacks and Whites, there is a challenge of the self-gratifying fantasy. In these plays, Blacks often control Whites and have access to white women. However, their power is simply an illusion. He grants certain fantasies to his black characters, tests them, and asks them if anything has really been accomplished by achieving Whites. It Bees Dat Way, for example, in forcing an encounter between Blacks and Whites in the audience, explores the "liberal" reaction to black life by testing it. The effect is to enlighten both the whites and black members of the audience. In its concluding comment to the black members of the audience, the play admonishes them that any pleasure they might have experienced watching the Whites being harassed arises from their own misdirected hostility. A Minor Scene depicts "black-militant-white-liberal" interaction in a playful mode. In it, Peter Black asks Miss Ann, "Hey you scummy lookin' bourgeois white bitch take me to dinner?" (Minor 78) taken aback at first, Miss Ann even threatens to call the police, but within minutes she is offering him a choice of cuisine and herself for desert-in polite language that contrasts ludicrously with his obscene suggestions.

It Has No Choice examines relationships between Blacks and Whites more comprehensively. It concerns the relation between Steve and Grace. Grace confesses to Steve that although her physical relationship with him has made her happier then she has been years, she wishes to end it because she does not love him. Steve replies:

I told you, Grace, not to come to me until you had fully made your free choice ... remember, when it happens, it has no choice . . . no, not at all, baby. It was your choice the moment you decided. And I'm holding you to it. (It Has 52)

They begin to fight hysterically; he subdues her and almost strangles her, then releases her and dresses. Looking down at Grace as she struggles back to consciousness, he says, "Same time tomorrow, okay? . . . I think I'll enjoy making love to you tomorrow, darling" (It Has 53). At the play's conclusion, it is Grace who has no choice: having placed herself in Steve's power, she must remain his. And he is as bound to her by his self-confessed love and hatred as she is to him by force. "The dream of myself isn't complete without you," he tells her (It Has 53). Thus, his sense of power is finally illusory, and the world unmasks itself neither to Grace, the victim, nor to Steve, the philosopher, but only to the audience. The play is in every sense ironic.

For Bullins, then, the image of the black man apparently in control of a white woman, while a gratifying fantasy of historical and symbolic significance, is bitterly ironic. His first full-length play depicting race relations is The Pig Pen. It portrays an interracial party set in Los Angeles in 1965, on the night of the assassination of Malcolm X. The announcement of his death brings the party and the play to a close. Although the action on stage is essentially realistic, slight distortions of time and space and of characterization direct attention to the symbolic significance of what occurs. Ostensibly the pig referred to in the title is a "white pig," dressed in a police uniform and blowing a whistle, and 
occasionally dancing across the stage. Pig also means loose woman, and perhaps the most striking feature of the hospitality offered by Len and Sharon, the interracial couple who give the party. White Sharon spends most of her time in the bedroom with any guest who desire her. Black Len does not object. He tells the others: "There is no need to envy me . . . my brothers . . . I willingly share with my brothers all I have. For what we have to share is really love" (The Pig 99). Almost all the guests take a turn with Sharon during the course of the evening.

Bullins's plays about revolution and race relation differ in several ways from those by Baraka treating similar themes. For example, where Baraka dares his audience to consider the imaginative possibility of violent revolution, Bullins assumes and tests this scenario by the depiction of human life so that the quality of other human life may be improved. Bullins neither advocates nor deplores violent revolution; he simply mistrusts. Moreover, while Baraka depicts Blacks as enslaved by white culture and an imposed white consciousness, and focuses on the act of liberation, Bullins depicts his characters as time and again freely choosing white values, often symbolized by white women.

The serious plays included in Bullins's first anthology, Five Plays by Ed Bullins, exemplify his explorations of the experiences of ordinary black life. These plays depict the people who struggle for their freedom, but bind themselves to old places and sustain old wounds rather than transform their lives. A Son, Come Home relates the history of a black family through an encounter between mother and son. The story is simple. After an absence of nine years, Michael has come to visit his mother who has become a religious fanatic and lives in a tyrannical Church-run home. Their conversation evokes painful memories in both. Finally, the mother retreats into her religious environment, and the son returns to his life. The mood of the play is almost sad. Each joyous moment in mother's and son's encounter turns out to be a sorrowful moment. The dominant theme of the play is the family bond: the mother repeatedly reminds Michael to contact his aunt Sophie, rebuking him for losing touch with her and telling him they are so alike. Michael's memories, not expressed to his mother, reveal that his aunt threw him out of her house after a week's visit and later refused a simple request for help when he was in trouble. Clara's Ole Man depicts the family as well and provides a grotesque, bitter comment on the structure often used to describe black family organization: matriarchy. For the play cites a litany of failures in nurturing.

Similarly, in Goin' a Buffalo, the presence of an outsider forces the characters to reveal themselves, and stripes them of certain illusions. But Art, the outsider in this play, is not innocent, when the characters open to him, they become his victims. Each member of the community of pimps, whores, and hustlers depicted in the play has individual illusions, and together they share a single dream: "goin' a Buffalo" to start a new:

Curt: It's a good little hustlin' town, I hear ...

Pandora: With me workin' on the side and with Curt dealin' we'd be on our feet in no time. (31-32).

However, their dream does not come to pass in the way they imagined it. The dream itself is problematic. Their plan, the same hustle but with a clean record, suggests the characters can imagine no real change or moral rebirth. Moreover, Los Angeles-the city Bullins refers to as "the last shore" in The Reluctant Rapist-has been kind to none of the characters, and their desire to go east suggests that even the hustlers' version of the American Dream has crumbled. 


\section{Conclusion}

What distinguishes Bullins's quest from others with similar concerns is that he seeks a definition arising from the imaginative and social context in which his characters live, through which they understand themselves. The question "What does it mean to be a black man?" for Bullins means "What does it mean to be a man?" By Black he does not mean black-as-opposed-to-white, like Baraka. He does not, even unconsciously, depict modes of behavior that counters insidious stereotypes. Moreover, Bullins generates values out of the experience of his characters, rather than imposing them from outside. His focus is the experiential knowledge of good and evil that he believes is present in everyone, except those whose understanding is distorted by drugs, violence, and all they represent. He is neither philosopher nor moralist, but he is absolutely certain that the human quest has a purpose. The structure of that quest evolves from the people whose quest it is, from their experience. The world he depicts pursues self-understanding on its own terms, in its own language, and by its own standards. In his plays, Black figures stand in Black ground, they no longer symbolize the "Other," and are, therefore, capable of achieving selfunderstanding.

\section{Works Cited}

Baraka, Amiri. The Baptism and The Toilet. New York: Grove/Atlantic, Inc., 1967. Print.

Bullins, Ed. Five Plays by Ed Bullins. New York: Bobbs-Merrill, 1968. Print.

---. Four Dynamite Plays. New York: Morrow, 1972. Print.

---. "Theatre of Reality." Negro Digest. XV (April, 1966): 60-66. Print.

Marvin X. "The Black Ritual Theatre: An Interview with Robert Macbeth." Black

Theatre. No. 3 (1969): 20-24. Print.

Sanders, Leslie Catherine. The Development of Black Theater in America: From Shadows to Selves. Baton Rouge \& London: Louisiana State University Press, 1988. Print. 